\title{
WEB SITE CONTENTS OF MUNICIPAL TRANSPORT UNDERTAKING AS A MODERN COMMUNICATION TOOL FOR ENHANCING QUALITY OF TRANSPORT SERVICES
}

The paper deals with web site contents of Municipal Transport Undertakings. In the paper there are introduced kinds of information in use improving and intensifying communication between customers (passengers) and transport operators. These data come from research results of several Municipal Transport Undertaking web sites.

There is also mentioned an informative minimum, which is found to be necessary and should not be omitted.

\section{Introduction}

At present the Internet plays an important role in citizens' lives as a source of information. Urban transport is not an exception as well. Quality level of web site contents of particular urban transport systems varies from municipality to municipality [1]. Data used for this article have come from a wide self-analysis of Municipal Transport Undertaking (MTU) web sites in the Czech Republic. Their list does not have to be definitive.

Czech MTU web sites were compared with MTU sites in Germany or in German speaking countries.

The level of basic essential transportation information is quite the same. German web sites contain more advertisements and their visual impression is fancier. It seems the accent is put more on impression than on content comparing to Czech web sites. On the other hand there are few Czech MTU web sites having a translation to foreign language. This shortage is found necessary to be improved. The authors don't regard the level of Czech MTU web sites as being worse than the level of those abroad.

\section{Web site content of Municipal Transport Undertakings}

Below there is a basic information structure appearing at many either official or, in some cases, unofficial web sites of MTU systems:

a) General information:

- basic data about the Urban Transport Operator,

- contacts;

b) Transport information:

- basic information about the urban transport system,

- a journey map or an interactive journey map,
- list of stations and stops,

- stop timetables or line timetables,

- connection searching,

- information of tie-in system P+R (Park \& Ride), B+R (Bike \& Ride) and $\mathrm{K}+\mathrm{R}$ (Kiss \& Ride),

- information for disabled persons,

- service centres,

-W@P and SMS services;

c) tariff information

- fares, tickets and tariff zones,

- full condition of carriage (+ also abstract),

- inspection + competence of inspector,

- where to buy a ticket,

- prepaid chip cards;

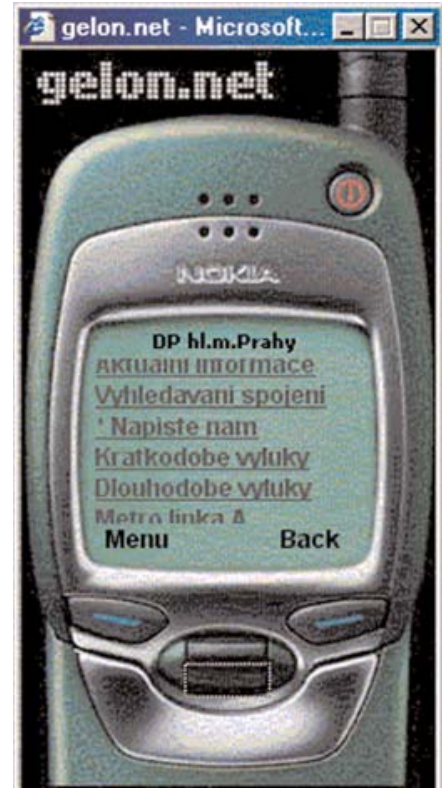

Fig.1. Wapalizer of W@P pages of MTU in Prague

\footnotetext{
* Pavel Drdla, Jan Hrabáček

Department of Transport Technology and Control, Jan Perner Transport Faculty, University of Pardubice, Studentská 95, CZ-53210 Pardubice, tel. ++420-466036204, fax. ++420-466036303, E.mail: Pavel.Drdla@upce.cz, Jan.Hrabacek@upce.cz
} 
d) service changes and disruptions:

- long-term service changes,

- short-term service changes,

- topical information about urban transport,

- future plans and changes;

e) passenger help and services:

- help, complaint procedure,

- important places (offices, schools, hospitals ...),

- street and stop searching,

- lost property;

f) other information and matters of interests:

- history of urban transport,

- photos,

- interesting things concerning urban transport,

- special periodical edited by the operator,

- fan-club,

- promotion and special trips (special transport service, historical cars, etc.)

- contests, games, entertainment;

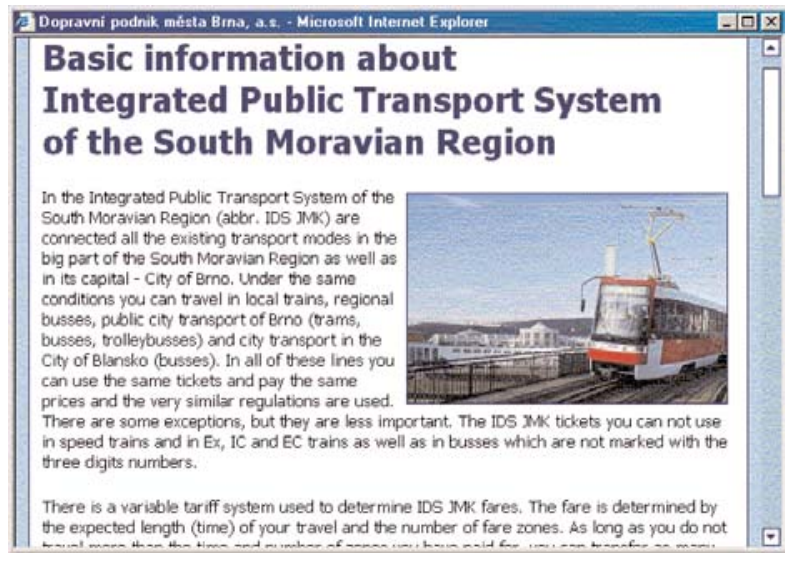

Fig. 2: Basic information about urban transport system (Brno)

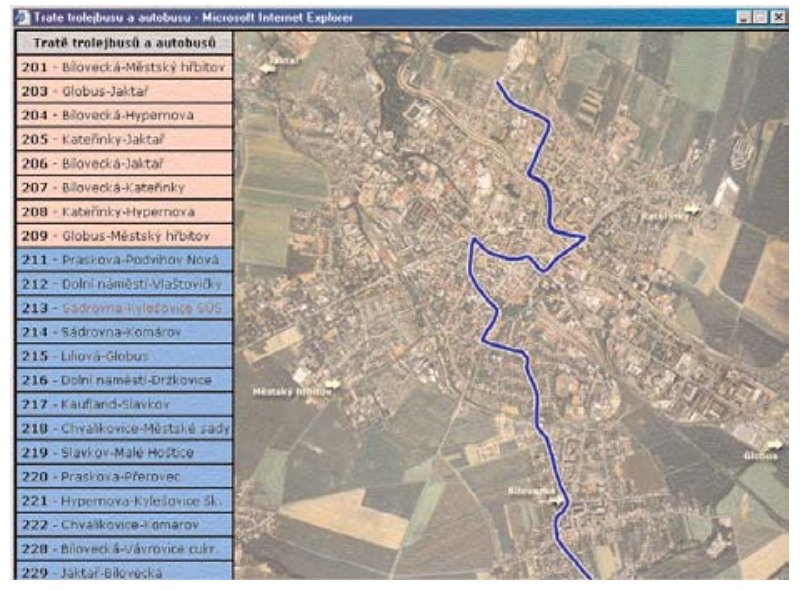

Fig. 3: Interactive journey map (Opava) g) others:

- job opportunities,

- additional services (car repair shop, tire service, car-wash, advertisement on vehicles etc.),

- other information (press releases, articles concerning urban traffic and MTU etc.);

- useful links,

- questionnaires, quizzes,

- FAQ's,

- views of passengers (discussion group),

- other web site properties (sitemap, searching, up-dating ...).

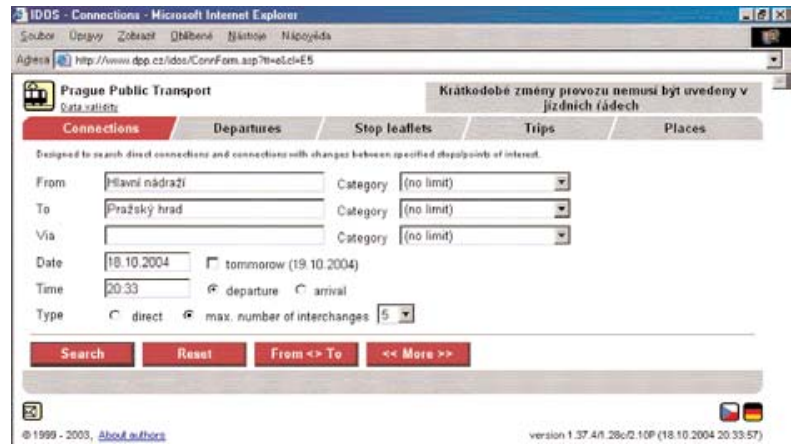

Fig. 4: Connection searching - input data (Prague)

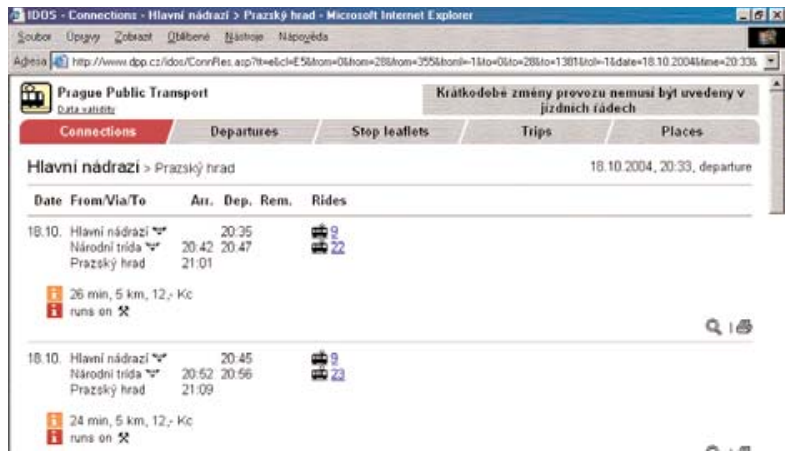

Fig. 5: Connection searching - output data (Prague)

\section{Web site informative minimum}

It stands to reason that the above mentioned list of several links is not used to such an extent at the biggest Municipal Transport Undertakings [2]. Though, the bigger the municipality (and its transport undertaking) the better and more extensive the content of its web sites.

Nevertheless, so-called informative minimum of web sites of any MTU system should be maintained. Every MTU system is supposed to present itself on the internet as a modern communicative tool.

Below, there are minimal web site data concerning an urban traffic operation:

- basic data about the urban service operator and contact,

- basic data about the urban service system, 


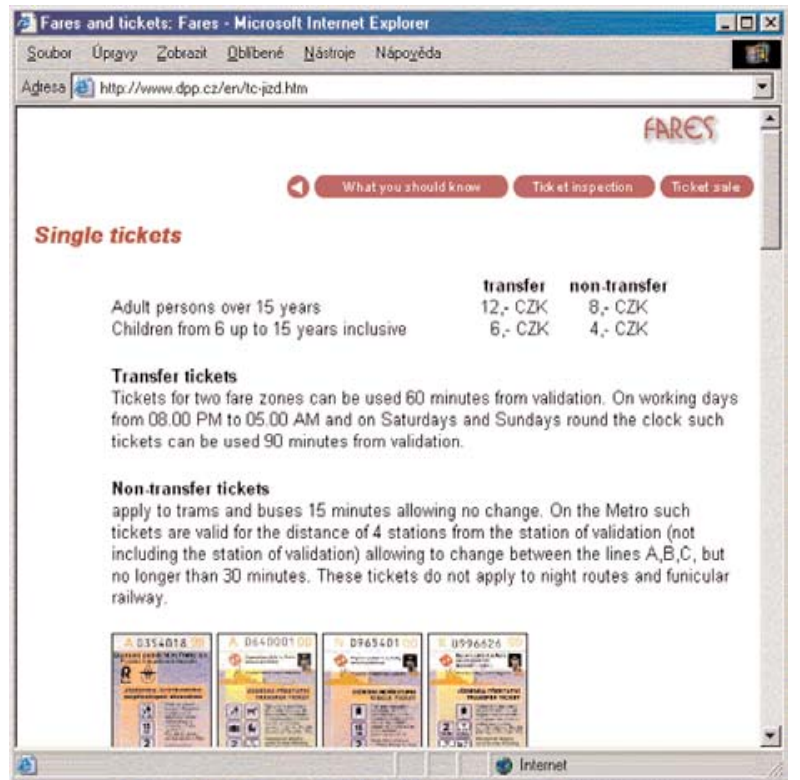

Fig. 6: Tariff information (Prague)
- a journey map,

- timetables,

- fares and tickets and tariff zone information,

- full conditions of carriage,

- real time information and service changes and disruptions.

In this case a passenger is not provided with enough information. He or she could perceive it as partial operator's lack of interest for customer and his or her transportation and enhancing of transportation quality in general.

\section{Conclusion}

The authors of the paper tried to summarise the problem of Municipal Transport Undertaking web site contents in connection with its practical daily use in relevant transport systems in the Czech Republic.

According to the authors improving the quality of communication between passenger and operator via internet as a modern communication tool contributes to the increase of consciousness of the MTU system in any municipality. Both authors welcome any comments on this topic.

\section{References}

[1] web sites of Municipal Transport Undertakings: www.dpp.cz, www.dpmb.cz, www.dpmost.cz, www.dpmp.cz, www.dpmhk.cz, www.dpml.cz, www.dpmdas.cz, www.dszo.cz, www.dpmo.cz, www.dpmul.cz, www.mdpo.cz, www.dpmcb.cz, www.dpmj.cz, www.tradomad.cz, www.dpplzen.cz, www.mhd-zr.aktualne.cz, www.bvg.de, www.dpb.sk, www.wiennet.at, www.mvv-muenchen.de, www.koelnverkehr.de, www.bsag.de, www.cvag.de, www.heag.de, www.dvv-dessau.de, www.dsw.ag, www.dvbag.de, www.dvv.de, www.evag.de, www.vgf-ffm.de, www.gvbgera.de, www.havag.de, www.uestra.de, www.hvv-heidelberg.de, www.hcr-herne.de, www.jenah.de, www.kvg.de, www.kvb-koeln.de, www.swk.de, www.lvb.de, www.mvg-mainz.de, www.mvv.de, www.mbk.de, www.vag.de, www.stoag.de, www.vwg.de, www.rsag-online.de, www.ssb-ag.de, www.swu.de, www.wvv.de, www.wsw-online.de

[2] internal data of Municipal Transport Undertakings in the Czech Republic 